Article

\title{
International Alliance of Green Hotels to Reach Sustainable Competitive Advantages
}

\author{
Hufei Ge ${ }^{1}$, Silu Chen ${ }^{2, *}$ and Yujie Chen ${ }^{3}$ \\ 1 School of Economics and Management, Southeast University, Nanjing 212000, China; 101011504@seu.edu.cn \\ 2 School of Economics and Business Administration, Central China Normal University, Wuhan 430079, China \\ 3 Faculty of Hospitality and Tourism Management, Macau University of Science and Technology, Taipa, \\ Macau 00853, China; yjchen@must.edu.mo \\ * Correspondence: chensilu@mail.ccnu.edu.cn
}

Received: 22 January 2018; Accepted: 18 February 2018; Published: 24 February 2018

\begin{abstract}
Under increasing environmental pressure, hotel firms need to improve their ability to access international alliances while maintaining good performance for sustainable development. This paper uses survey data from 784 hotels running at different levels of service in China to test the hypothesis in an integrated analytical model, and the findings show that the impact of international alliances varies with different levels of green hotels. Despite operating in the same sector, hotels running at different levels of service vary their respective tactics to gain sustainable competitive advantage and achieve significantly different results. This study intends to inform hotel managers in obtaining specific performance goals by developing absorptive capacity, and by choosing the most suitable alliance for their level of operation.
\end{abstract}

Keywords: absorptive capacity; management contract; joint venture; franchising; green hotel

\section{Introduction}

In response to serious environmental concerns, the hotel industry is emphasizing energy conservation, environmental protection and sustainable development by reducing waste, recycling materials, and reusing resources [1]. As hotels are highly vulnerable to external factors and pressures in a global operating environment [2], many hotels are trying to adopt low-carbon energy technologies or green management to address environmental demand. For example, certain hotels use low-carbon energy technologies to reduce the cost of stabilizing atmospheric carbon dioxide concentrations [3]. Other hotels adjust their management style to increase consumer loyalty and promote new sales [4]. However, the prevalence of green hotel concepts and technologies does not match other developing countries. So entering into international alliances may increase their rate of adoption.

Given today's institutional environment, if a hotel fails to meet the environmental demand of stakeholders, it may lose its legitimacy for operating in business and fall behind its competitors. Based on this view, successfully applying the knowledge already acquired by partners in international alliances is an effective way for domestic firms to improve management. Another aim is to ensure that employees in the hotel industry perform in an environmentally friendly manner, and that the given hotels meet the standards of corporate social responsibility. Absorptive capacity has typically been suggested as an important business attribute for local firms that want to develop their own systems for cost saving and waste reduction [5]. Absorbing business strategy, technology, and innovative management concepts from foreign partners through international alliances can build sustainable competitive advantages. Each form of international alliance, such as management contracts, joint ventures, and franchising, has a unique influence on both local firms and their international partners. To this end, a central concern for all parties is how to choose suitable alliance modes to enhance the ability of absorptive capacity from international operations and allow them to exploit new 
opportunities in international markets. In fact, a systematic review of the literature on innovation in service sector businesses [6] confirms the almost complete absence of research into the absorptive capacity of hotels and other tourism businesses in spite of the extensive "mainstream" (notably manufacturing) literature.

Moreover, although the effects of international alliances on firm performance have been analyzed in industrial and manufacturing sectors, studies in the hotel industry are limited. Knowledge and information technology are seen as the primary drivers of growth in all sectors. Green hotels, as their security and social benefits are protected, have a broader space for development and prospects than traditional hotels. In order to satisfy customers' green preferences and their demand for sustainable development, promotion of learning and sharing information is crucial. To protect the efficiency and effect of management, the cooperation between domestic and international partners is usually adopted [7].

In response to the need for further studies on the relationship between international alliances and performance, this study provides a theoretical framework that supports the transfer of one firm's competencies to another through an alliance. A firm's superior performance is a consequence of obtaining and sharing knowledge among different partners and within its departments [8]. Under this situation, absorptive capacity creates the opportunity for hotels to engage in green management, and the hotel needs to acquire diverse knowledge and employ know-how to fully exploit useful knowledge [9]. Since different types of alliance modes are not equally efficient in promoting green management's performance, we further examine whether the mediating role of absorptive capacity is contingent upon different alliance modes for hotels to apply knowledge to develop new products or service, exploit new business opportunities, and gain sustainable competitive advantages. To accomplish our goal, the paper builds a conceptual model, shown in Figure 1, to analyze the relationship among international alliance types, absorptive capacity, strategic objectives, and final performance.

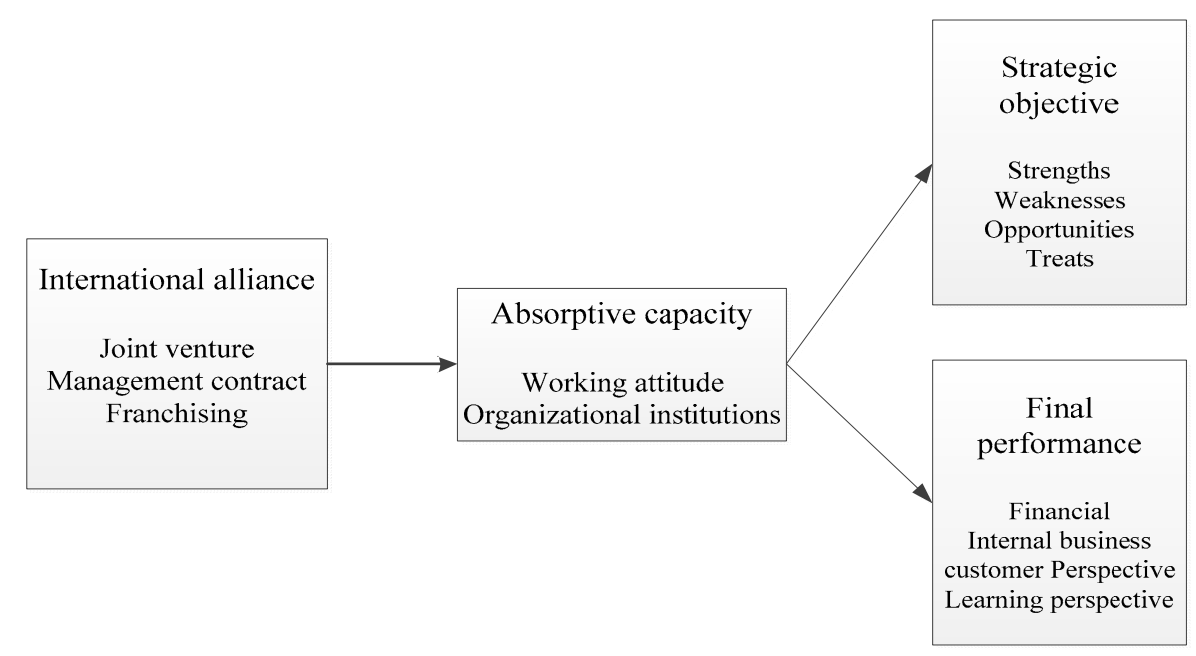

Figure 1. The concept model.

\section{Literature Review and Proposed Hypotheses}

\subsection{Absorptive Capacity}

How can a firm utilize organization-level arrangements so as to facilitate this kind of learning process among core employees and then translate such learning outcomes into sustainable competitive advantages? [10]. Absorptive capacity enables an organization to recognize, evaluate, assimilate, and apply new knowledge to commercial use [11,12]. Firms with absorptive capacity are better at resource utilization, building core technologies, and are more competent in all respects [13]. From these 
viewpoints of scholars, absorptive capacity is kind of continuous absorption, digestion and utilization capacity, also an exploratory learning ability to gain knowledge sources from other enterprises and internal and external environment [14]. According to the resource-based view (RBV), selecting and accumulating resources are functions of both within-firm decision making and external strategic factors [15]. In the hotel industry, firms with increased absorptive capacity can exploit their internal strength and fill structural holes in business operations more efficiently.

Absorptive capacity is seriously impacted by the working attitude of employees and organizational institutions [16]. The criteria for job satisfaction are subjective while those that cover working conditions are objective $[17,18]$. Here, subjective job satisfaction, rather than good working conditions, means high motivation rather than high degrees of loyalty, which promotes employees' willingness to appreciate, collect, and assimilate knowledge from the external environment, especially from acquisitions and other inter-organizational relations. Therefore, this study assumes that if employees possess a positive attitude, they will take more responsibility to recognize and evaluate the potential of new knowledge and create more learning opportunities within the organization [19]. On the other hand, normative contexts can range from strong top-down policies to mutually evolving regulations. In other words, the greater the normative embedded in the organization, the more likely that the organization will be reactionary and convergent rather than evolutionary and radical [20]. For instance, employees who have been externally compelled or pressured to engage in their task may feel psychologically entitled to some form of recompense from the organization if they are in a negative mood. Therefore, management style and institutional climate have significant effects on organization members' behaviors, and their interest in learning, transferring, exploiting, and generating new knowledge.

\subsection{TheRelationship between International Alliance and Absorptive Capacity}

Research suggests that different types of alliance modes are associated with the firm's absorptive capacity, which, in turn, determines firm performance [20]. Hence, hotel managers need detailed knowledge about learning attributes to be able to identify the critical issues that will lead to performance improvement. The following section illustrates the relationship between different alliance modes and absorptive capacity:

\subsubsection{Management Contract and Absorptive Capacity}

Management contract is a long-term business deal whereby the legal owners of the property enter into a contract with the firm to manage the daily operation, usually under the operator's internationally recognized brand image [21]. Because of their experience in the hotel industry, these firms are better equipped for management than less sophisticated owners, and they are given substantial power and control over operations [22].

With contract agreements, local hotels can learn operating skills and marketing strategies and can establish networks with global partners, thus enhancing the brand name and reputation demanded by hotel managers and investors. Indeed, the learning process depends on absorptive capacity. Some management experiences are learned by doing, which enables local hotels to develop new routines that influence knowledge exchange and generation. This, in turn, influences value creation for competitive advantage and enhances innovation performance [23].

\subsubsection{Joint Venture and Absorptive Capacity}

A joint venture occurs when assets are brought together for a limited period of time by two or more owners and operated as one business entity [24,25]. Joint ventures are often preferred to full ownership because they can help international firms adapt quickly to new markets by combining local industry knowledge, operating processes, and providing access to larger distribution networks [26]. This business structure is often used for large resort complexes and luxury hotels where local hotels are pursuing financial support for new projects and/or commitments from hotel chains. 
In joint ventures, local hotels can help their international partners respond to political factors, economic regulations and cultural norms that are embedded in national environments. When the cost of acquiring new assets becomes prohibitive, joint ventures can allow operations to proceed and owners' goals to be attained [27]. Consequently, absorptive capacity could facilitate the accumulation of local experience and save transaction costs. In addition, local hotels can learn advanced management skills from international partners when evaluating, assimilating, and applying advance management concepts, which may result into newly joint-patented technologies or products [28].

\subsubsection{Franchising and Absorptive Capacity}

In franchising, the international partner train and guide local hotels with respect to management and quality control under a contractual relationship, sharing only some tacit expertise. They do not directly control operations [24]. According to Grunhagen and Dorsch (2003) [29], the franchisor-franchisee relationship represents a partnership conducted as a form of relational exchange.

Because international partners offer marketing experience, reservation systems and other forms of assistance, local hotels working with franchisors can adjust their production and management activities and build market share [30]. In this franchising relationship, the free flow of information and technology will be enhanced, allowing local hotels to transform and exploit their management skills and to increase their ability to use knowledge. Under this structure, local hotels can also benefit from the reputation and branding of the international franchisor, which positively affects the overall performance at the alliance and/or firm levels [28].

\subsection{Established Hypotheses}

\subsubsection{Current Status of Green Hotels}

More recently, sustainability has become an important issue within businesses, arising from concerns over natural resources depletion, wealth disparity, and social responsibility [31]. In this regard, hotels at different levels of operation have begun to adopt green management to keep pace with the trend towards "going green". One of the behaviors of green management is to improve the quality of hotel service, for instance, identifying the differences among customers' green perceptions, enhancing the knowledge of customers' green demand, and improving service practices accordingly [32]. When comparing the leading international green hotels, we find that some have adapted well, while others still have work to do, and we will offer suggestions to address these issues for different levels of local hotels.

\subsubsection{Economy Hotels}

Hotels operating at the economy level provide basic food, drink and accommodation rather than upgrades such as entertainment [33]. Accordingly, providing clean, green, and low-priced rooms is the core service element. Inexpensive rooms attract budget-conscious customers who would not be interested in mid- or high-service hotels. The challenge for these hotels is to acquire more extensive geographic coverage of their network of hotels and new knowledge regarding how to reduce expenditures and maintain their quality of green service. A joint venture with leading partners may enable local hotels to enter a new market in a short period of time, achieving large economies of scale with minimal access costs and relatively low levels of risk.

Hypothesis 1. The most suitable alliance mode for economy hotels should be joint venture.

\subsubsection{Mid Service Level Hotels}

The middle level of hotels is expanding significantly with the rapid growth of China's economy and business activities, leading to the birth and growth of hotel chains. The most evident benefit of 
chain hotels is derived from the brand, which provides hotels with the direct image and reputation of the brand [25]. Branding provides greater market visibility, solidifies a firm's position in the emerging green market niche and helps the firm to overtake the competition. For middle-level hotels, the acquisition of a distinct green image is paramount as an irreplaceable service. Entering a franchise arrangement with leading partners will allow a firm to acquire advanced technologies and skills that are not part of the hotel's existing knowledge base and to apply these technologies and skills to advance the brand name.

Hypothesis 2. The most suitable alliance mode for middle-level hotels should be franchising.

\subsubsection{High Service Level Hotels}

High-level hotels in China are confronted by a series of problems that must be resolved quickly, including the following: employees who lack adequate knowledge about green service; energy-inefficient appliances that must be upgraded; and management teams that may not be equipped to address international cultural conflicts that may arise. Thus, this type of hotel must acquire advanced appliances, green services and products and must promote a professional management style to achieve long-term sustainable development in localization. The management contract with leading partners will enhance operating efficiency, improve capital investment in terms of infrastructure and facilities and minimize cultural conflicts.

Hypothesis 3. The most suitable alliance mode for high-level hotels should be management contract.

\subsubsection{Alliance Mode Comparison}

Working under management contracts encourages the flow of knowledge to and from the external environment and offers ways to increase the amount of flow within a firm. Employees tend to have strong common beliefs and a clear corporate vision [34]. A flexible and harmonious operations management style facilitates positive exchanges between managers and employees and leads to high employee motivation and commitment [35]. As a consequence, employees working within this framework tend to have favorable working attitudes and more job satisfaction. Thus, relaxed management controls are more suitable for companies with less stringent institutional environments. The relationship between the strategic objectives and extracted critical success factors (CSFs) of operations for management contracts is stronger than for joint ventures and franchising. International alliances favor management contracts in regard to strategic decision making.

Hypothesis 4. Comparing the relative coefficients among different alliance modes, the management contract has the best executive capabilities for reaching strategic objectives.

Efficiency (such as higher profit and lower cost) and effectiveness (such as tighter schedule and better quality) are watchwords for joint ventures. However, developing operational efficiency and effectiveness may result in employees with lower levels of motivation and commitment [35]. In addition, one joint venture partner may retain exclusive control over the global brand name while sharing responsibility for day-to-day operations management. Employees who work under this management framework tend to have less favorable working attitudes [34]. Tight management controls are appropriate when the institutional environment is more rigorous and conservative. The relationship between extracted CSFs of operation and final performance in joint ventures is stronger than for management contracts and franchising. Alliances tend to favor joint ventures when operational level decision making is considered to be more important. 
Hypothesis 5. Comparingthe relative coefficients among different alliance modes, the joint venture should have the best executive capabilities for reaching operational objectives.

Although management contracts often feature better organizational learning because they operate under more elastic institutional environments and involve motivated and committed employees, owners may not always be content with their passive role [24]. Joint venture strategies may provide them with more control when in less flexible institutional environments in which employees exhibit poorer working attitudes. The majority of middle-level hotels favor franchising because this approach strikes a balance between these two opposing modes and produces the best outcomes.

Hypothesis 6. Comparingthe relative consistency coefficients among different alliance modes, franchising is better than either the joint venture or the management contract.

\section{Data Analysis and Results}

\subsection{The Performance of Hotels}

\subsubsection{Strategic Indicators}

Strategic objectives can help a firm to achieve a sustainable competitive advantage such as relative cost or differentiation positions [36]. For example, a firm can produce similar quality goods at a lower cost than its competitors, or higher quality goods at the same cost [37]. Green hotels have unique characteristics when compared to conventional hotels. This study employs four commonly used strategic indicators: strengths, weakness, opportunities, and treats for green hotel firms. It views strategic alliances as a way to absorb critical skills from international partners. This involves external acquisition and internal knowledge transfer, and it is always an implicit strategic objective for every firm that chooses to enter into alliances [38]. Indeed, alliances not only allow trading access to complementary capabilities, but can also result in full internalization or absorption of a partner's skills [39].

\subsubsection{Critical Successful Characteristics (CSFs) of Operations}

CSFs of operations for green hotels are essential since they provide a clear understanding for local firms to learn and apply advanced knowledge from successful examples. The Delphi method was used to identify the most valuable CSFs of operations for green hotels. This method structures a group to deal effectively with a complex problem [40]. 18 managers were invited to participate: 6 from economy, 6 from middle level and 6 from high service level hotels. Using both closed and open-ended questions, they were asked how to manage green hotels successfully. We generated 16 CSFs of operations for green hotels and adopt factor analysis in the following section.

\subsubsection{Performance Indicators}

Four performance indicators were chosen: financial, internal business, customer perspective, and learning perspective for green hotels [39,41-43]. Financial performance includes financial ratios, stock prices and/or risk, market sales, and financial margins. Internal business includes employee training, investments in energy or water saving equipment, efficiency of production, and differentiated green brand image. Customer perspective includes customer satisfaction level, green service quality, and average occupancy rate. Learning perspective includes knowledge and intelligent capital, innovative green products, advanced environmental technology.

\subsection{Participants and Procedure}

We conducted interviews with 18 managers from hotels at different service levels in the mainland China in the begging of 2017. We generated 4 strategic objects, 16 possible CSFs of green hotels, 
and 4 final performance evaluations in the questionnaire (from "not agree at all" = 1 to "strongly agree" equivalent $=5$ ). Questionnaires, as shown in the Appendix A, were distributed to managers from high-level, middle-level, and economic-level green hotels in China. Using a 5-point Likert scale, respondents were asked to answer sample questions such as the following: To what extent do you think the following factors are critical to successful green hotel management? Of the 3610 questionnaires sent to managers in the three types of service level hotels, 784 were retained for analysis, showing an effective response rate of $21.73 \%$. The distribution of the sample hotels was as follows: 25 economy hotels (i.e., Seven-Days, Home Inn, Hanting, etc.), with 247 surveys; 21 mid-level hotels (i.e., All Seasons, Yaduo hotel, Selected Home Inn, etc.), with 231 surveys; and 20 high-service hotels (i.e., Hyatt, Shangri-La, Hilton, etc.), with 306 surveys. A statistical analysis of the returned questionnaires shows average variance extracted ranges from 0.718 to 0.869 , which meets the convergence validity criteria [44]. Cronbach's alpha ranges from 0.728 to 0.828 , which are all higher than 0.7 , showed high reliabilities, as presented in Table 1.

Table 1. Reliability and validity coefficients at different stages of questionnaires.

\begin{tabular}{cccc}
\hline Research Stage & Questions & AVE & Cronbach $\alpha$ \\
\hline Strategic Objective Stage $^{\text {a }}$ & 4 & 0.813 & 0.796 \\
CSF of Operation Stage $^{\mathrm{b}}$ & 16 & 0.718 & 0.728 \\
Final Performance Stage $^{\mathrm{c}}$ & 4 & 0.869 & 0.828 \\
\hline
\end{tabular}

Note a: strategic objectives include strengths, weakness, opportunities, and treats; b: critical success characteristics of operations for green management are listed in Table 2; c: modified BSC includes financial, internal business, customer and learning perspectives.

\subsection{Factor Analysis}

After previous literature reviews and the Delphi method, the paper collected 16 CSFs for green hotels (including financial benefits of green design, economic profitability growth, positive public attention, and ISO/Eco certification, lowered cost for energy-efficient and water-efficient appliances, cost of employees' professional training, operating costs associated with purchasing environmentally friendly products, customers not willing to pay a premium, coping with environmental regulation, better public images with customer community, satisfying environmental future, mutually learning effects, social gaps within social interaction and customer network tie, hard work with suppliers to develop energy-saving products, difficult employee recognition, and difficult customer recognition) [8,45-51]. Factor analysis was performed using SPSS 20.0. 4 critical factors with Eigenvalues larger than one were extracted, and these were treated as critical dimensions, and they explained $69.68 \%$ of the variance in the collected data sets. Varimax with Kaiser Normalization was then carried out to name these extracted dimensions. Critical success characteristics with a loading value greater than 0.4 were collected and put together in the same dimension. The results are indicated in Table 2.

Table 2. Factor analysis for critical characteristics of green hotel.

\begin{tabular}{|c|c|c|c|c|}
\hline & $\begin{array}{c}\text { Dimension Name } \\
\text { Critical Factors of Operations }\end{array}$ & Eigenvalue & $\begin{array}{l}\text { Variance } \\
\quad(\%)\end{array}$ & $\begin{array}{l}\text { Cumulative } \\
\text { Variance (\%) }\end{array}$ \\
\hline 1. & $\begin{array}{c}\text { Strengths } \\
\text { financial benefits of green design, economic } \\
\text { profitability growth, positive public attention, and } \\
\text { ISO/Eco certification }\end{array}$ & 7.32 & 23.66 & 23.66 \\
\hline 2. & $\begin{array}{l}\text { Weakness } \\
\text { lowered cost for energy-efficient and water-efficient } \\
\text { appliances, cost of employees' professional training, } \\
\text { operating costs associated with purchasing } \\
\text { environmentally friendly products, and customers } \\
\text { not willing to pay a premium }\end{array}$ & 5.57 & 17.42 & 41.08 \\
\hline
\end{tabular}


Table 2. Cont.

\begin{tabular}{|c|c|c|c|c|}
\hline & $\begin{array}{c}\text { Dimension Name } \\
\text { Critical Factors of Operations }\end{array}$ & Eigenvalue & $\begin{array}{c}\text { Variance } \\
(\%)\end{array}$ & $\begin{array}{l}\text { Cumulative } \\
\text { Variance (\%) }\end{array}$ \\
\hline 3. & $\begin{array}{c}\text { Opportunities } \\
\text { coping with environmental regulation, better public } \\
\text { image with customer community, satisfying } \\
\text { environmental future, and mutual learning effects }\end{array}$ & 3.92 & 16.82 & 57.90 \\
\hline 4. & $\begin{array}{l}\text { Threats } \\
\text { social gaps within social interaction and customer } \\
\text { network ties, hard work with suppliers to develop } \\
\text { energy-saving products, difficult employee } \\
\text { recognition, and difficult customers recognition }\end{array}$ & 1.57 & 11.78 & 69.68 \\
\hline
\end{tabular}

\subsection{Cluster Analysis}

We employed the ANOVA test with the Benforroni post-hoc pairwise comparison test to verify the proposed hypotheses. Table 3 shows that the forms of alliance (joint venture, franchising and management contract) have different characteristics. Their relationships are significantly different at 0.05 level, except for public attention, lowered cost for efficient appliances, customers not paying a premium, coping with environmental regulation, social gaps within customer network, and hard work with suppliers. First, this indicates that the most important characteristics for joint ventures are financial benefits, employees' training costs and operating costs. These are congruent with the pursuit of effectiveness and efficiency. Second, this indicates that the most important characteristics for management contracts are ISO/Eco certification, public attention, customer recognition, and satisfying environmental future. This aligns with the pursuit of better public image, and social connections within customer networks that are characteristic of alliances built around management contracts. Third, it implies that the most important characteristics for franchising are profitability growth, mutual learning effects, and employee recognition. The results are reasonable, since the characteristics of franchising are mutual learning and long-term profitability growth.

Table 3. Suitable alliance modes for specific characteristics of alliance modes.

\begin{tabular}{|c|c|c|c|c|}
\hline $\begin{array}{c}\text { Different Modes of Alliance } \\
\text { Different Characteristics of Mode }\end{array}$ & $\begin{array}{c}\text { Joint } \\
\text { Venture }\end{array}$ & $\begin{array}{l}\text { Management } \\
\text { Contract }\end{array}$ & Franchising & F (or K) \\
\hline \multicolumn{5}{|l|}{ Financial benefits } \\
\hline Cluster mean & $3.62^{a}(2,3)^{b}$ & $2.79(1)$ & $2.71(1)$ & $\begin{array}{c}13.17^{\mathrm{c}} \\
p<0.038\end{array}$ \\
\hline \multicolumn{5}{|l|}{ Profitability growth } \\
\hline Cluster mean & $3.12(2,3)$ & $3.83(1)$ & $3.92(1)$ & $\begin{array}{c}12.17 \\
p<0.049\end{array}$ \\
\hline \multicolumn{5}{|l|}{ Public attention } \\
\hline Cluster mean & 3.52 & 3.86 & 3.28 & $\begin{array}{c}3.72 \\
p<0.182\end{array}$ \\
\hline \multicolumn{5}{|l|}{ ISO/Eco certification } \\
\hline Cluster mean & $2.18(2,3)$ & $3.61(1,3)$ & $3.23(1,2)$ & $\begin{array}{c}12.24 \\
p<0.047\end{array}$ \\
\hline \multicolumn{5}{|l|}{ Lowered cost for efficient appliances } \\
\hline Cluster mean & $3.89(2,3)$ & $2.25(1)$ & $2.71(1)$ & $\begin{array}{c}9.59 \\
p<0.057\end{array}$ \\
\hline \multicolumn{5}{|l|}{ Cost of employees' training } \\
\hline Cluster mean & $4.19(2,3)$ & $2.46(1)$ & $2.79(1)$ & $\begin{array}{c}15.29 \\
p<0.031\end{array}$ \\
\hline Operating costs & & & & \\
\hline Cluster mean & $4.02(2,3)$ & $2.52(1)$ & 2.83(1) & $\begin{array}{c}16.29 \\
p<0.028\end{array}$ \\
\hline
\end{tabular}


Table 3. Cont.

\begin{tabular}{|c|c|c|c|c|}
\hline $\begin{array}{l}\text { Different Modes of Alliance } \\
\text { Different Characteristics of Mode }\end{array}$ & $\begin{array}{l}\text { Joint } \\
\text { Venture }\end{array}$ & $\begin{array}{l}\text { Management } \\
\text { Contract }\end{array}$ & Franchising & F (or K) \\
\hline \multicolumn{5}{|l|}{ Customers not paying a premium } \\
\hline Cluster mean & 2.61 & 2.82 & 2.23 & $\begin{aligned} & 7.29 \\
p & <0.093\end{aligned}$ \\
\hline \multicolumn{5}{|l|}{ Coping with environmental regulation } \\
\hline Cluster mean & 2.35 & 3.67 & 3.42 & $\begin{array}{c}8.13 \\
p<0.087\end{array}$ \\
\hline \multicolumn{5}{|l|}{ Better public image } \\
\hline Cluster mean & $2.89(2,3)$ & $4.33(1,3)$ & $3.91(1,2)$ & $\begin{array}{c}11.22 \\
p<0.049\end{array}$ \\
\hline \multicolumn{5}{|l|}{ Satisfying environmental future } \\
\hline Cluster mean & $2.47(2,3)$ & $4.49(1)$ & $4.33(1)$ & $\begin{array}{c}14.34 \\
p<0.033\end{array}$ \\
\hline \multicolumn{5}{|l|}{ Mutual learning effects } \\
\hline Cluster mean & $2.86(2,3)$ & $3.73(1,3)$ & $4.36(2,3)$ & $\begin{array}{c}16.72 \\
p<0.026\end{array}$ \\
\hline \multicolumn{5}{|l|}{ Social gaps within customer network } \\
\hline Cluster mean & 2.96 & 3.93 & 3.85 & $\begin{array}{c}7.24 \\
p<0.107\end{array}$ \\
\hline \multicolumn{5}{|l|}{ Work with suppliers } \\
\hline Cluster mean & 2.83 & 2.41 & 2.58 & $\begin{array}{c}5.29 \\
p<0.125\end{array}$ \\
\hline \multicolumn{5}{|l|}{ Employee recognition } \\
\hline Cluster mean & $2.91(2,3)$ & $3.72(1,3)$ & $4.23(1,2)$ & $\begin{array}{c}11.29 \\
p<0.047\end{array}$ \\
\hline \multicolumn{5}{|l|}{ Customer recognition } \\
\hline Cluster mean & $2.76(2,3)$ & $3.85(1)$ & $3.46(1)$ & $\begin{array}{c}9.21 \\
p<0.61\end{array}$ \\
\hline
\end{tabular}

Note a: Mean based on 5-point Likert scale comparing the data collected in the beginning of 2017; b: Numbers in parentheses indicate the cluster groups from which this cluster is significantly different at $\alpha=0.05$ according to the Bonferroni, post-hoc pairwise comparison procedures; $\mathrm{c}$ : F and corresponding $\mathrm{p}$-values based on ANOVA test.

\subsection{Path Analysis}

Here, we test the hypotheses through path analysis. Firstly, the relationship between 4 strategic objectives and 4 extracted CSFs are examined; and then, the relationship between 4 extracted CSFs and 4 indices of final performance are examined.

\subsubsection{Management Contract (from 231 Questionnaires)}

In path analysis model (I), the relationships of 4 strategic objectives with 4 extracted CSFs are shown in Table 4. In path analysis model (II), the relationships of 4 extracted CSFs and 4 final performances are shown in Table 5. We cascade path analysis model (I) and (II) together to deduce the relation in the stages among strategic objectives, extracted CSFs and final performance.

Table 4. Path analysis between 4 strategic objectives and 4 extracted CSFs.

\begin{tabular}{cccc}
\hline $\begin{array}{c}\text { Dependent Variables } \\
\text { (Critical Characteristics for Hotels with } \\
\text { Green Management) }\end{array}$ & $\begin{array}{c}\text { Independent Variables } \\
\text { (4 Strategic Objectives) }\end{array}$ & Path Coefficients & Adjusted $\mathbf{R}^{\mathbf{2}}$ \\
\hline ISO/Eco certification & Strengths & $0.203^{* *}$ & 0.324 \\
Economic profitability growth & Strengths & $0.125^{*}$ & 0.324 \\
Cost of employees' professional training & Weakness & $0.221^{*}$ & 0.175 \\
Better public image with customer community & Opportunities & $0.328^{* *}$ & 0.397 \\
Mutual learning effects & Opportunities & $0.184^{*}$ & 0.397 \\
Difficult employee recognition & Threats & $0.182^{* *}$ & 0.231 \\
\hline
\end{tabular}

Note: Path analysis for management contract; ${ }^{*} p<0.10 ;{ }^{* *} p<0.05 ;{ }^{* * *} p<0.01$. 
Table 5. Path analysis between 4 extracted CSFs and 4 performance perspectives.

\begin{tabular}{|c|c|c|c|}
\hline $\begin{array}{l}\text { Dependent Variables } \\
\text { (Final Performance) }\end{array}$ & $\begin{array}{c}\text { Independent Variables } \\
\text { (Critical Characteristics for Hotels with } \\
\text { Green Management) }\end{array}$ & $\begin{array}{l}\text { Path } \\
\text { Coefficients }\end{array}$ & $\begin{array}{l}\text { Adjusted } \\
\qquad \mathbf{R}^{2}\end{array}$ \\
\hline Financial profitability & Economic profitability growth & $0.162 *$ & 0.219 \\
\hline Customer retention & Better public image with customer community & $0.247^{* *}$ & 0.287 \\
\hline Internal business & $\begin{array}{c}\text { Hard work with suppliers to develop } \\
\text { energy-saving products }\end{array}$ & $0.113 *$ & 0.187 \\
\hline Learning effects & Mutual learning effects & $0.107 *$ & 0.224 \\
\hline
\end{tabular}

Note: Path analysis for management contract; ${ }^{*} p<0.01 ;{ }^{* *} p<0.05 ;{ }^{* * *} p<0.01$.

\subsubsection{Joint Venture (from 267 Questionnaires)}

Similarly, path analyses for joint venture were carried out, and the results are shown in Tables 6 and 7.

Table 6. Path analysis between 4 strategic objectives and 4 extracted CSFs.

\begin{tabular}{cccc}
\hline $\begin{array}{c}\text { Dependent Variables (Critical Characteristics } \\
\text { for Hotels with Green Management) }\end{array}$ & $\begin{array}{c}\text { Independent Variables } \\
\text { (4 Strategic Objectives) }\end{array}$ & $\begin{array}{c}\text { Path } \\
\text { Coefficients }\end{array}$ & $\begin{array}{c}\text { Adjusted } \\
\mathbf{R}^{\mathbf{2}}\end{array}$ \\
\hline Financial benefits of green design & Strengths & $0.237^{* * *}$ & 0.294 \\
Coping with environmental regulation & Opportunities & $0.173^{*}$ & 0.289 \\
Difficult customer recognition & Threats & $0.186^{*}$ & 0.276 \\
\hline
\end{tabular}

Note: Path analysis is for joint venture, ${ }^{*} p<0.10 ;{ }^{* *} p<0.05 ; * * * p<0.01$.

Table 7. Path analysis between 13 extracted CSFs and 4 performance perspectives.

\begin{tabular}{|c|c|c|c|}
\hline $\begin{array}{l}\text { Dependent Variables } \\
\text { (Final Performance) }\end{array}$ & $\begin{array}{c}\text { Independent Variables (Critical } \\
\text { Characteristics for Hotels with Green } \\
\text { Management) }\end{array}$ & $\begin{array}{c}\text { Path } \\
\text { Coefficients }\end{array}$ & Adjusted $R^{2}$ \\
\hline \multirow[t]{2}{*}{ Financial profitability } & Economic profitability growth & $0.162 *$ & 0.357 \\
\hline & Financial benefits of green design & $0.108^{* *}$ & 0.357 \\
\hline \multirow[t]{2}{*}{ Customer retention } & Coping with environmental regulation & $0.185 *$ & 0.316 \\
\hline & Better public image with customer community & $0.247^{* *}$ & 0.316 \\
\hline Internal business & $\begin{array}{l}\text { Operating costs associated with purchasing } \\
\text { environmentally friendly products }\end{array}$ & $0.281 *$ & 0.293 \\
\hline Learning effects & Difficult customer recognition & $0.173^{* * *}$ & 0.293 \\
\hline
\end{tabular}

Note: Path analysis is for joint venture; ${ }^{*} p<0.10 ;{ }^{* *} p<0.05 ;{ }^{* * *} p<0.01$.

\subsubsection{Franchising (from 286 Questionnaires)}

Similarly, path analyses for franchising were carried out, and the results are shown in Tables 8 and 9.

Table 8. Path analysis between 4 strategic objectives and 4 extracted CSFs.

\begin{tabular}{cccc}
\hline $\begin{array}{c}\text { Dependent Variables } \\
\text { (Critical Characteristics for Hotels with } \\
\text { Green Management) }\end{array}$ & $\begin{array}{c}\text { Independent Variables } \\
\text { (4 Strategic Objectives) }\end{array}$ & $\begin{array}{c}\text { Path } \\
\text { Coefficients }\end{array}$ & $\begin{array}{c}\text { Adjusted } \\
\mathbf{R}^{\mathbf{2}}\end{array}$ \\
\hline $\begin{array}{c}\text { Financial benefits of green design } \\
\text { Economic profitability growth }\end{array}$ & Strengths & $0.208^{*}$ & 0.304 \\
Operating costs associated with purchasing & Strengths & $0.183^{* *}$ & 0.224 \\
environmentally friendly products & Weakness & $0.121^{*}$ & 0.175 \\
Mutual learning effects & Opportunities & $0.264^{*}$ & 0.283 \\
Better public image with customer community & Opportunities & $0.182^{* *}$ & 0.281 \\
\hline
\end{tabular}


Table 9. Path analysis between 4 extracted CSFs and 4 performance perspectives.

\begin{tabular}{cccc}
\hline $\begin{array}{c}\text { Dependent Variables } \\
\text { (Final Performance) }\end{array}$ & $\begin{array}{c}\text { Independent Variables (critical Characteristics } \\
\text { for Hotels with Green Management) }\end{array}$ & $\begin{array}{c}\text { Path } \\
\text { Coefficients }\end{array}$ & $\begin{array}{c}\text { Adjusted } \\
\mathbf{R}^{\mathbf{2}}\end{array}$ \\
\hline Financial profitability & $\begin{array}{c}\text { Economic profitability growth } \\
\text { Financial benefits of green design }\end{array}$ & $0.142^{* *}$ & 0.387 \\
Customer retention & Better public image with customer community & $0.178^{* *}$ & 0.387 \\
Internal business & Hard work with suppliers to develop & $0.119^{*}$ & 0.253 \\
Learning effects & energy-saving products & $0.261^{* * *}$ & 0.293 \\
\hline
\end{tabular}

Note: Path analysis for franchising; ${ }^{*} p<0.10 ;{ }^{* *} p<0.05 ;{ }^{* * *} p<0.01$.

\section{Discussion}

As shown in Table 3, since green economy hotels focus on efficiency, minimal capital investment, and short-term profitability, joint venture should be applied. Thus, hypothesis 1 is supported. Since middle service level green hotels emphasize mutual learning effects, better employee recognition, and long-term profitability, franchising should be used. Thus, hypothesis 2 is supported. Since the characteristics of alliance mode in the high levels of green hotels look for better public image, ISO/Eco certification, satisfying environmental future, and social connection within customer network, management contract should be adopted. Thus, hypothesis 3 is supported.

As shown in Tables 4, 6 and 8, path coefficients between strategic objectives and extracted CSFs of operations for joint ventures are smaller when compared with franchising and management contracts. To proceed from strategic objectives to extracted CSFs, a firm needs to add new content to existing routines, procedures, and learning systems by effectively managing knowledge flow between external and internal environments. Employees working under management contracts tend to have high job satisfaction, enjoy less stringent institutional environments and seem more involved. In joint ventures, employees have good attitudes and high loyalty to the company. They work in a better-defined institutional environment and may not have the same level of enthusiasm and commitment that can be found where management contracts have been applied. Since the coefficients between strategic objectives and extracted CSFs indicate executive capability at the strategic level, management contract has better executive capabilities in terms of reaching strategic objectives. Accordingly, hypothesis 4 is confirmed.

As shown in Tables 5, 7 and 9, path coefficients between extracted CSFs of operations and final performance under management contracts are smaller compared with joint ventures and franchising. Basically, during the process from extracted CSFs to final performance, a firm tries to enhance its business of various products and services to satisfy customers. In fact, most employees in joint ventures used to have good working attitudes from objective good conditions/high degrees of loyalty, tighter institutional environments/top-down policies, which may develop a sense of responsibility and lead to increasing their work outcomes. In contrast, management contract employees enjoy more flexible institutional environments and show high job satisfaction levels. They are more committed to obtaining good work outcomes. Since the coefficients between extracted CSFs and final performance indicate executive capability at the operational level, joint venture has better executive capabilities to obtain operational objectives. Therefore, Hypothesis 5 is verified.

When cascading the data in Tables 4 and 5, the same dimensions in both tables focus on organizational learning and better corporate reputation. There are positive path coefficients among strategic objectives, extracted CSFs and final performance for management contract. Thus, the results indicate that the alliance mode of management contract facilitates the transfer from tacit knowledge to explicit knowledge, which contribute to firm performance. Similarly, when cascading the data in Tables 6 and 7, the same dimensions in both tables focus on effectiveness and efficiency. This reinforces previous results indicating that the alliance mode of joint ventures pursues both efficiency and effectiveness in the place of learning and sharing knowledge. Lastly, when compared with management 
contracts (shown in Tables 4 and 5) and joint ventures (shown in Tables 6 and 7), the consistently relative coefficients between strategic objectives and final performance are better for franchising (shown in Tables 8 and 9). Thus, hypothesis 6 is proved.

\section{Implications and Limitations}

In an effort to probe into the relationship among strategic objectives, extracted CSF of operations, and firm performance for different modes of international alliance, a concept model by incorporating the absorptive capability of green hotel management is proposed. The international alliance facilitates the redeployment and reconfiguration of a firm's existing repertoire of knowledge. Such redeployment could affect strategic objectives and final performance. The theoretical implications and practical implications are as follows.

Firstly, this study advances our understanding of the role of international alliance in the development of "globalization and going green". The research on international alliances in green hotels supports previous literature with regard to other industries. As suggested above, an important reason here is the change in the institutional environments in the hotel industry, which can influence organizational institutions and determine their legitimacy. Regarding sustainability, green hotels should maintain international standards for products and services. In this case, operations and management style should provide a unique feeling for customers and other stakeholders. Secondly, since there are few studies on policies from the perspective of green hotel alliances, this study will contribute to the development of strategy to ensure the effectiveness and efficacy of international alliances. Greater absorptive capacity often leads to more sustainable competitive advantages, and the level or scale of it depends on the attitude of employees and their institutional working environment. This implies the merit of applying a Resource-based View in understanding the mediating effect of absorb capacity between international alliances and strategic objective/firm performance. Hotels in China should build their absorptive capacity to enhance mutual understanding, trust and cohesion. They can use international alliances to gain the knowledge essential for adaptation to today's fast-paced, rapidly changing environment.

This study has several limitations that must be addressed. First, the strategies for international alliances for green hotels vary among hotels, cultures, and economies. The participating hotels in this study include green hotels operating in China. Hence, the sample used in this study may not be representative of the wider hotel industry in other developing countries. To increase generalizability, future research should conduct a cross-culture analysis on the strategy of international alliances. Second, international alliances may take time to exert the maximum influence on hotel performance. The data for this study were collected at one point in time. Therefore, this research design may not enable the effect of international alliances to be fully explored. Future research should consider a longitudinal study on the outcomes of international alliances.

Acknowledgments: This work is financially supported by self-determined research funds of CCNU from the colleges' basic research and operation of MOE (CCNU17QN0006). National Science Fund of China (NSFC71602030).

Author Contributions: The research is designed and performed by Hufei Ge and Silu Chen. The data was collected by Hufei Ge. Analysis of data was performed by Yujie Chen and Silu Chen. Finally, the paper was written by Yujie Chen and Silu Chen. All authors read and approved the final manuscript.

Conflicts of Interest: The authors declare no conflict of interest. The founding sponsors had no role in the design of the study; in the collection, analyses, or interpretation of data; in the writing of the manuscript, and in the decision to publish the results.

\section{Appendix A. Major Questionnaire Items}

\section{Part 1: Basic Information}

1. Gender: Male, Female 
2. Position: General manager, Senior manager

3. Education: Senior high school, Bachelor degree, Master degree, $\mathrm{PhD}$

4. Tenure: Less than 5 years, $5-10$ years, $11-20$ years, More than 20 years.

5. How long has your hotel been established? Less than 5 years, 5-10 years, 11-20 years, More than 20 years.

6. What size of your hotel? Less than 100 people, 100-300 people, 301-500 people, More than 500 people.

Part 2: To What Extent Do You Think the Following Factors are Critical to Successful Green Hotel Management? Please Evaluate the Importance of the Following Dimensions

\begin{tabular}{|c|c|c|c|c|c|}
\hline \multirow{2}{*}{$\begin{array}{l}\text { Characteristic Factors for Green Hotels } \\
\text { Extremely unimportant (1) to extremely important (5) }\end{array}$} & \multicolumn{5}{|c|}{ Degree of Important } \\
\hline & 1 & 2 & 3 & 4 & 5 \\
\hline \multicolumn{6}{|l|}{ Strengths } \\
\hline \multicolumn{6}{|l|}{ Financial benefits of green design } \\
\hline \multicolumn{6}{|l|}{ Economic profitability growth } \\
\hline \multicolumn{6}{|l|}{ Positive public attention } \\
\hline \multicolumn{6}{|l|}{ ISO/Eco certification } \\
\hline \multicolumn{6}{|l|}{ Weakness } \\
\hline \multicolumn{6}{|l|}{ Sunk cost for energy-efficient and water-efficient appliances } \\
\hline \multicolumn{6}{|l|}{ Cost on employees' professional training, } \\
\hline \multicolumn{6}{|l|}{ Operating costs associated with purchasing environmentally products } \\
\hline Customers may not be willing to pay a premium...... & & & & & \\
\hline
\end{tabular}

Part 3: to What Extent Do You Think the Above Factors are Suitable for Different Levels of Green Hotels? Please List the Factors

\begin{tabular}{ccc}
\hline Types of International Alliance & $\begin{array}{c}\text { Characteristic Factors for } \\
\text { Green Hotels }\end{array}$ & $\begin{array}{c}\text { Levels of Green Hotels (Economy, } \\
\text { Middle-Service, High-Service) }\end{array}$ \\
\hline $\begin{array}{c}\text { Joint Venture } \\
\text { Management Contract } \\
\text { Franchising }\end{array}$ & & \\
\hline
\end{tabular}

\section{References}

1. Hsiao, T.Y.; Chuang, C.M.; Kuo, N.W.; Yu, S.M.F. Establishing attributes of an environmental management system for green hotel evaluation. Int. J. Hosp. Manag. 2014, 36, 197-208. [CrossRef]

2. Ritchie, B.W. Chaos, crises and disasters: A strategic approach to crisis management in the tourism industry. Tour. Manag. 2004, 25, 669-683. [CrossRef]

3. Albino, V.; Ardito, L.; Dangelico, R.M.; Petruzzelli, A.M. Understanding the development trends of low-carbon energy technologies: A patent analysis. Appl. Energy 2014, 135, 836-854. [CrossRef]

4. Prendergast, G.; Man, H.W. The influence of store image on store loyalty in Hong Kong's quick service restaurant industry. J. Foodser. Bus. Res. 2002, 5, 45-59. [CrossRef]

5. Pereira-Moliner, J.; Claver-Cortés, E.; Molina-Azorín, J.F.; Tarí, J.J. Quality management, environmental management and firm performance: Direct and mediating effects in the hotel industry. J. Clean. Prod. 2012, 37, 82-92. [CrossRef]

6. Carlborg, P.; Kindström, D.; Kowalkowski, C. The evolution of service innovation research: A critical review and synthesis. Serv. Ind. J. 2014, 34, 373-398. [CrossRef]

7. Liu, A.; Liu, H.; Xiao, Y.; Tsai, S.B.; Lu, H. An empirical study on design partner selection in green product collaboration design. Sustainability 2018, 10, 133. [CrossRef]

8. Dev, C.S.; Erramilli, M.K.; Agarwal, S. Brands across borders: Determining factors in choosing franchising or management contracts for entering international markets. Cornell Hotel Restaur. Adm. Q. 2002, 43, 91-104. [CrossRef] 
9. Liu, C.H.; Lee, T. Promoting entrepreneurial orientation through the accumulation of social capital, and knowledge management. Int. J. Hosp. Manag. 2015, 46, 138-150. [CrossRef]

10. Chang, S.; Gong, Y.; Way, S.A.; Jia, L. Flexibility-oriented HRM systems, absorptive capacity, and market responsiveness and firm innovativeness. J. Manag. 2013, 39, 1924-1951. [CrossRef]

11. Minguela-Rata, B.; Rodríguez-Benavides, M.C.; López-Sánchez, J.I. Knowledge complexity, absorptive capacity and weak ties: An empirical analysis of its effects on franchise systems uniformity. J. Manuf. Technol. Manag. 2012, 23, 578-592. [CrossRef]

12. Chuang, M.Y.; Chen, C.J.; Lin, M.J. The impact of social capital on competitive advantage. Manag. Decis. 2016, 54, 1443-1463. [CrossRef]

13. Melkas, H.; Uotila, T.; Kallio, A. Information quality and absorptive capacity in service and product innovation processes. Interdiscip. J. Inf. Knowl. Manag. 2010, 5, 357-374. [CrossRef]

14. Jiang, Y.; Chun, W.; Yang, Y. The effect of external relations network on low-carbon technology innovation: Based on the study of knowledge absorptive capacity. Sustainability 2018, 10, 155. [CrossRef]

15. Cooke, F.L.; Saini, D.S. How does the HR strategy support an innovation oriented business strategy? An investigation of institutional context and organizational practices in Indian firms. Human Res. Manag. 2010, 49, 377-400. [CrossRef]

16. Chen, H.H.; Lee, A.H.; Xing, X.; Chen, H. The relationships of different modes of international alliance with performance of renewable energy enterprises. Renew. Energy 2014, 69, 464-472. [CrossRef]

17. Gallie, D. Employment Regimes and the Quality of Work; Oxford University Press: Oxford, UK, 2007.

18. Robbins, S.P.; DeCenzo, D.A. Fundamentals of Management: Essential Concepts and Applications; Pearson Prentice Hall: Upper Saddle River, NJ, USA, 2007.

19. Pittz, T.G.; Intindola, M. Exploring absorptive capacity in cross-sector social partnerships. Manag. Decis. 2015, 53, 1170-1183. [CrossRef]

20. Zahra, S.A.; Hayton, J.C. The effect of international venturing on firm performance: The moderating influence of absorptive capacity. J. Bus. Ventur. 2008, 23, 195-220. [CrossRef]

21. Gannon, J.; Roper, A.; Doherty, L. The impact of hotel management contracting on IHRM practices: Understanding the bricks and brains split. Int. J. Contemp. Hosp. Manag. 2010, 22, 638-658. [CrossRef]

22. Goddard, P.; Standish-Wilkinson, G. Hotel management contracttrends in the Middle East. J. Leis. 2001, 2, 66-80.

23. Capaldo, A.; Petruzzelli, A.M. In search of alliance-level relational capabilities: Balancing innovation value creation and appropriability in R\&D alliances. Scand. J. Manag. 2011, 27, 273-286.

24. Contractor, F.J.; Kundu, S.K. Modal choice in a world of alliances: Analyzing organizational forms in the international hotel sector. J. Int. Bus. Stud. 1998, 29, 325-357. [CrossRef]

25. Ivanova, M.; Ivanov, S. Affiliation to hotel chains: Hotels' perspective. Tour. Manag. Perspect. 2015, 16, 148-162. [CrossRef]

26. Makino, S.; Neupert, K.E. National culture, transaction costs, and the choice between joint venture and wholly owned subsidiary. J. Int. Bus. Stud. 2000, 31, 705-713. [CrossRef]

27. Yiu, D.; Makino, S. The choice between joint venture and wholly owned subsidiary: An institutional perspective. Organ. Sci. 2002, 13, 667-683. [CrossRef]

28. Capaldo, A.; Petruzzelli, A.M. Partner geographic and organizational proximity and the innovative performance of knowledge-creating alliances. Eur. Manag. Rev. 2014, 11, 63-84. [CrossRef]

29. Grunhagen, M.; Dorsch, M.J. Does the franchisor provide value to franchisees? Past, current, and future value assessments of two franchisee types. J. Small Bus. Manag. 2003, 41, 366-384. [CrossRef]

30. Pine, R.; Zhang, H.Q.; Qi, P.S. The challenges and opportunities of franchising in China's hotel industry. Int. J. Contemp. Hosp. Manag. 2000, 12, 300-307. [CrossRef]

31. Hallam, C.; Contreras, C. Integrating lean and green management. Manag. Decis. 2016, 54, $2157-2187$. [CrossRef]

32. Hu, M.L.M.; Horng, J.S.; Sun, Y.H.C. Hospitality teams: Knowledge sharing and service innovation performance. Tour. Manag. 2009, 30, 41-50.

33. Gilbert, D.C.; Arnold, L. Budget hotels. Leis. Manag. 1989, 9, 61-63.

34. Fligstein, N. Social skill and institutional theory. Am. Behav. Sci. 1997, 40, 397-405. [CrossRef]

35. Covaleski, M.A.; Dirsmith, M.V. An institutional perspective on the rise, social transformation, and fall of a university budget category. Adm. Sci. Q. 1988, 33, 562-587. [CrossRef] 
36. Besanko, D.; Dranove, D.; Shanley, M. Economics of Strategy; John Wiley \& Sons: New York, NY, USA, 1996.

37. Walker, M.M. Corporate takeovers, strategic objectives, and acquiring-firm shareholder wealth. Financ. Manag. 2000, 29, 53-66. [CrossRef]

38. Yoshino, M.; Rangan, U.S. Strategic Alliances: An Entrepreneurial Approach to Globalization; Harvard Business School Press: Boston, MA, USA, 1995.

39. Kale, P.; Singh, H.; Perlmutter, H. Learning and protection of proprietary assets in strategic alliances: Building relational capital. Strateg. Manag. J. 2000, 21, 217-237. [CrossRef]

40. Chen, S.L.; Liu, C.K.; Iao, L.L.; Chen, H.H. The impact of learning effects of environmental management system on performance of renewable energy firms. Environ. Prog. Sustain. Energy 2015, 34, 1106-1112. [CrossRef]

41. Sharma, A.; Upneja, A. Factors influencing financial performance of small hotels in Tanzania. Int. J. Contemp. Hosp. Manag. 2005, 17, 504-515. [CrossRef]

42. Sainaghi, R. Hotel performance: State of the art. Int. J. Contemp. Hosp. Manag. 2010, 22, 920-952. [CrossRef]

43. Wang, C.H.; Chen, K.Y.; Chen, S.C. Total quality management, market orientation and hotel performance: The moderating effects of external environmental factors. Int. J. Hosp. Manag. 2012, 31, 119-129. [CrossRef]

44. Fornell, C.; Larcker, D.F. Evaluating structural equation models with unobservable variables and measurement error. J. Mark. Res. 1981, 18, 39-50. [CrossRef]

45. Han, H.; Hsu, L.T.J.; Sheu, C. Application of the theory of planned behavior to green hotel choice: Testing the effect of environmental friendly activities. Tour. Manag. 2010, 31, 325-334. [CrossRef]

46. Kuminoff, N.V.; Zhang, C.; Rudi, J. Are travelers willing to pay a premium to stay at a "green" hotel? Evidence from an internal meta-analysis of hedonic price premier. Agric. Res. Econ. Rev. 2010, 39, 468-484. [CrossRef]

47. Segarra-Oña, M.; Peiró-Signes, A.; Verma, R.; Miret-Pastor, L. Does environmental certification help the economic performance of hotels? Evidence from the Spanish hotel industry. Cornell Hosp. Q. 2012, 53, 242-256. [CrossRef]

48. Rahman, I.; Reynolds, D.; Svaren, S. How "green" are North American hotels? An exploration of low-cost adoption practices. Int. J. Hosp. Manag. 2012, 31, 720-727. [CrossRef]

49. Chen, Y.C.; Chen, Y.T. The advantages of green management for hotel competitiveness in Taiwan: In the viewpoint of senior hotel managers. J. Manag. Sustain. 2012, 2, 211-218. [CrossRef]

50. Kang, K.H.; Stein, L.; Heo, C.Y.; Lee, S. Consumers' willingness to pay for green initiatives of the hotel industry. Int. J. Hosp. Manag. 2012, 31, 564-572. [CrossRef]

51. Gu, H.; Ryan, C.; Bin, L.; Wei, G. Political connections, guanxi and adoption of CSR policies in the Chinese hotel industry: Is there a link? Tour. Manag. 2013, 34, 231-235. [CrossRef] 